
U. S. DEPARTMENT OF AGRICULTURE. BUREAU OF CHEMISTRY - BULLETIN NO. 125.

H. W. WILEY, CHIEF OF BEREAU.

\section{THE CANNING OF PEAS,}

BASED ON FACTORY INSPECTION AND EXPERIMENTAL DATA.

\section{BY}

A. W. BITTING,

Fuod Inspector, Buresu of Chemintry.

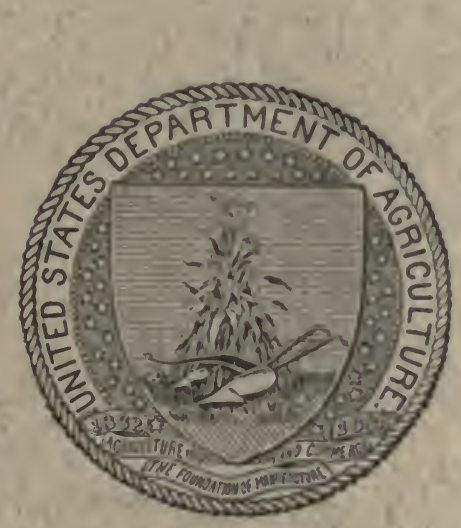

WASHINGTON:

GOVERNMENT PRINTING OFFICE. 1909. 


\section{LETTER OF TRANSIITTAL.}

U. S. Departyent of Agriculture,

Bureau of Chemistry,

Washington, D. C., March 1, 1909.

SIR: I have the honor to submit herewith for your consideration and approval a manuscript on "The Canning of Peas." This industry has grown to very large proportions in the United States, and it is thought that the results of the investigations made by Inspector Bitting, as based on a year's inspection and experimentation, while not final in some particulars will yet be of interest and utility to the manufacturer as suggesting methods for a more economical treatment of the raw material and better sanitary conditions in the factory. The bulletin will also be of interest to the consumer in indicating the method of preparation of an article of diet which has come so generally into deserved favor in this country. I recommend that this report be published as Bulletin 125 of the Bureau of Chemistry.

Respectfully,

H. W. WILEY,

Hon. Jases Wilsox,

Chief.

Secretary of Agriculture. 


\section{CONTENTS.}

Page.

The pea

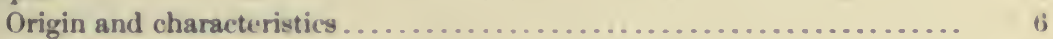

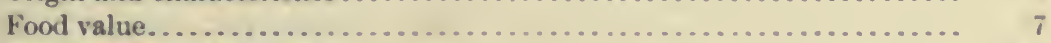

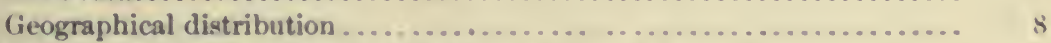

Production of peas especially for canning....................... \& 8

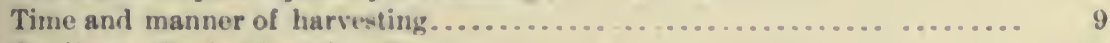

Grading and valuation of crop................................ 10

Factory operations ............................................ 11

Vining or thrashing .................................... 11

Washing...................................................... 12

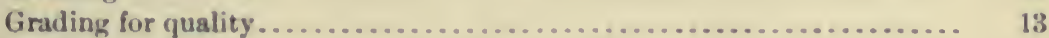

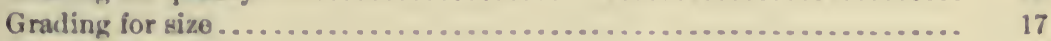

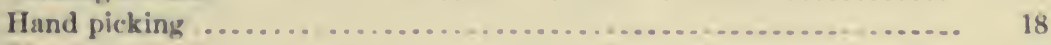

Blanching .......................... 19

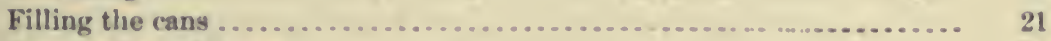

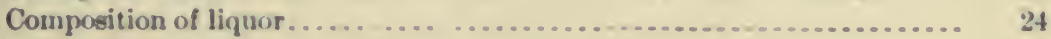

Processing ............................................. 24

Cooling the finished product ............................... 27

Examination of commercial cunnerl peas........................ 27

Spoilage ............................................... 29

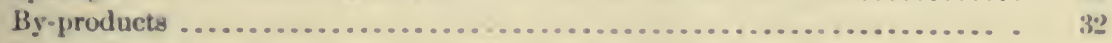

\section{II.I.USTRATIONS.}

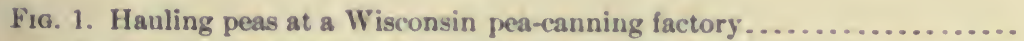

2. Interior of cannery showing squirrel cages for washing peas and the brine tanks where they are graded according to quality......... 13

3. Testing the peas in a salt solution for quality.................. 14

4. Separation of three grades of peas by suspension in salt solutions .... 15

5. A molem aanitary pea-canning plant...................... 17

6. A battery of filling machines............................ 22 
Digitized by the Internet Archive in 2007 with funding from Microsoft Corporation 


\section{THE CANNING OF PEAS.}

\section{HISTORICAL NOTE.}

According to the early accounts of the art of canning, peas were among the first vegetables to be preserved in this manner, and later they were among the first to enter the canned-goods trade. Pea canning may be said, therefore, to be as old as the canning industry. It first the process was used only to preserve such choice fruits and regetables as were most difficult to keep in the fresh state, as the cost of glass bottles and earthenware jars prevented their use for cheaper products. After the invention of the tin can, as the cost was lessened, peas became one of the most important articles packed. The pea-canning industry began in this country in Baltimore during the Fifties. There was an immediate demand for the product, and consequently some packing was done at nearly every factory. The peas were grown garden fashion and picked and podded by hand; but the labor required was so great that the output was small and the price high. The methods used did not differ in any essential detail from those followed in preparing fresh peas in the kitchen. The demand continued to increase. but the total output of all the early factories would not equal that of one small modern plant.

The first labor-saving device of importance in pea canning was the podding machine invented by Madame Faure in France in 1883. This machine was described in La Nature, Paris, April, 1885, and a translation, with illustrations, appeared in the Scientific American June 6, 1855. The invention was practically duplicated in this country in 1859. By means of the podding machine one person could do the work of a hundred or more in removing the peas from the pods, thus making possible the canning of much greater quantities. The American podding machine was improved, and in 189:3 It was patented as a vining machine. After this invention it was no longer necessary to pick the pods from the vines in the field: the plants could be mowed, hauled in by wagon, and the peas separated from the pod and vine at one operation. The whole pea-canning industry was changed by this invention. Practically all of the peas canned in this country are passed through these rining machines, so that their use has virtually changed the growing of peas in small patches-market-garden fashion, with hundreds of persons going 
over the vines and picking the pods-to the cultivating of large fields which are cut by a machine. The, viner occupies the same relation to hand picking in the pea-canning industry that the thrashing machine does to the flail in the thrashing of wheat.

Pea canning is one of the most important lines of the canning industry, being third in order of output, tomatoes and corn being. respectively, first and second, although peas are second in point of value. The pea pack for 1907 is estimated at $6,505,961$ cases, valued at $\$ 14,650,000$, the largest amount ever packed in one season. According to the statistics given by The Canner and Dried Fruit Packer of December 26, 1907, the production of peas in the different States during 1907 was as follows:

Peas canned during 190\%, by states.

\begin{tabular}{|c|c|c|c|}
\hline Californial _... & $\begin{array}{l}\text { Cases. } \\
90,450\end{array}$ & Minnesota - & $\begin{array}{l}\text { Cases. } \\
25,750\end{array}$ \\
\hline Colorado, Idaho, Utah, and & & New Jersey _-_._-_. & 153,564 \\
\hline Oregon & 193,018 & New York _...... & $1,659,944$ \\
\hline Delaware & 141,046 & Ohio & 101,521 \\
\hline Illinois _. & 216,508 & Pennsylvani:ı _.. & 80,373 \\
\hline Indiana _... & 826,500 & Virginia _-_-_ & 15,486 \\
\hline Iowa - & 50,000 & Wisconsin _...... & $1,773,599$ \\
\hline Kansas _. & 11,589 & Other States & 3,132 \\
\hline Maryland _-_-_-_- & 568,393 & & \\
\hline Michigan _.... & 595,088 & Total United States & $6.505,961$ \\
\hline
\end{tabular}

\section{THE PEA.}

\section{ORIGIN AND CHARACTERISTICS.}

The pea belongs to the Leguminosæ, an order of plants which is of great economical value, as many of its members yield foods. drugs, dyes, and valuable woods. Chief among their products are peas, beans, lentils, peanuts, tamarinds, licorice, senna, gum tragacanth, gum arabic, logwood, indigo, rosewood, locust, and Brazil wood.

The origin of the pea is unknown, but it is supposed to have been carried to Europe by the Aryans at a remote period. The field pea, Pisum arvense, is found wild in Italy, but the garden pea, Pisum sativum, grows only under cultivation, so far as known. In Queen Elizabeth's time peas were occasionally brought from Holland and considered "a dainty dish for ladies, they came so far and cost so dear." The taste for green peas became fashionable after the Restoration in 1660 , and their culture was given much attention, later becoming so general as to be one of the most important field crops. Garden peas were considered a delicacy, and the French gave considerable attention to their culture and canning, and through selection they developed varieties yielding tender small peas of fine flavor. The pea was brought to North America by European colonists, and grown in kitchen and market gardens. 
FOOD VALC'E.

Of all vegetables known the legumes are the richest in respect to their nitrogenous content, Knight going so far as to claim that they will be found equal to meat in nutritive powers for active open-air workers. Statements of this nature are not true of. green peas, but apply to the mature seeds only. The following analyses show the results obtained on the mature pea, and also on the green pea before and after canning.

Results of imalyse's of pras.

MII:I) I'F:IS.

\begin{tabular}{|c|c|c|c|c|c|c|}
\hline Analywe. & Water. & Proteln. & Fat. & $\begin{array}{l}\text { Starch, } \\
\text { elc. }\end{array}$ & $\begin{array}{l}\text { Cellu- } \\
\text { lose. }\end{array}$ & - Ash. \\
\hline 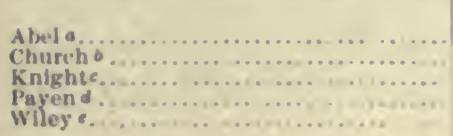 & $\begin{array}{r}\text { Iter cent. } \\
9.30 \\
14.80 \\
14.81 \\
8.80 \\
12.62\end{array}$ & $\begin{array}{r}\text { Per cent. } \\
24.60 \\
22.40 \\
23.63 \\
23.80 \\
27.04\end{array}$ & $\begin{array}{r}\text { Per cent. } \\
1.00 \\
2.80 \\
1.72 \\
2.10 \\
1.58\end{array}$ & $\begin{array}{r}\text { Per cent. } \\
62.00 \\
51.30 \\
53.24 \\
58.70 \\
51.75\end{array}$ & $\begin{array}{r}\text { Per cent. } \\
6.50 \\
5.45 \\
3.50 \\
3.90\end{array}$ & $\begin{array}{r}\text { Per cent. } \\
2.00 \\
3.00 \\
2.65 \\
2.10 \\
3.11\end{array}$ \\
\hline
\end{tabular}

(i16 K:F:X PFIS.

\begin{tabular}{|c|c|c|c|c|c|c|}
\hline Aled $\ldots, \ldots \ldots \ldots \ldots \ldots \ldots$ & 71. (10) & $\div .00$ & 0.50 & $f 16.90$ & & 1. 00 \\
\hline Whley .......... . n & $\div 9.98$ & 3.87 & .49 & 13.30 & 1.63 & .78 \\
\hline
\end{tabular}

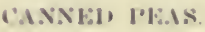

\begin{tabular}{|c|c|c|c|c|c|c|}
\hline Alvel. & $\times 5.30$ & 3150 & 0.20 & f 9.80 & …....... & -1.10 \\
\hline Wiley. & $\times 5.47$ & 3.37 & .21 & 7.79 & 1.18 & 1. 11 \\
\hline
\end{tabular}

- Ibs, Friedenwald and liuhrih. Dlet In Health and Disease, p. 91, 1905.

- Food, p. 83, 1887.

- Foud and Its Functions, 189.

- Abs. Pavy. F. W. Food and Dietefles, P. 167, 1 .S81.

- Foods and Thelr Adulteration, pp. 2x5, 313, 1907.

Including cellulose.

According to these figures, the average amount of protein in the dry peas is 24.09 per cent, in the green peas 5.44 per cent, and in the canned peas 3.59 per cent, indicating that the canned peas lost some protein during the preliminary treatment. Leach states that 2.03 per cent of the protein of the pea is soluble in water, and 10 per cent in salt solution. These figures were eviclently for the mature pea. Church states that the predominating protein in leguminous plants appears to be more soluble and more easily digested in the green than in the mature seed. In the preparation of peas for canning, they pass through a washer, where they are sprinkled with cold water, and then go to the picking tables, still wet, and after this into the blancher containing hot water. The length of time that the peas are in the washer varies in the factories, while the time they remain in the blancher depends upon the grade and size of the. peas, varying 
from one to twelve minutes. After leaving the blanchers, the peas are placed in the cans as quickly as the machines will work, and the brine is filled in at the same time. From the treatment it is apparent that the peas may lose some protein before entering the cans, and that more may dissolve in the brine after they are in the cans. A part of the loss of protein in canning is, however, more apparent than real, as the peas take up water in blanching and processing, thus increasing their total weight, which only seemingly reduces the proportion of protein.

The liquor from peas which had been canned in water, and also liquor from peas canned in brine, were tested for protein. While the reactions with the water extract indicated distinct traces of protein, those with the brine were much more pronounced. Some of the canners advise the use of the original pea liquor in the preparation of the peas for the table, supposedly with the object of utilizing the extracted foods. Usually the liquor is discarded as being somewhat objectionable in odor.

\section{GEOGRAPHICAL DISTRIBCTION.}

While the growing of peas is not limited to any one particular part of the United States, they are grown with the greatest success where the spring is a little slow in changing from cool to warm weather. The northeastern and north central parts of the country grow most of the peas, Wisconsin leading in their production, closely followed by New York. These two States produce almost one-half of the entire pea pack of the country. Indiana, Michigan, Maryland, Illinois, New Jersey, Delaware, Ohio, California, Pennsylvania, Iowa, Minnesota, Virginia, and Kansas follow in order. Peas are also being packed in Colorado, Idaho, Utah, and Oregon, but they can not be grown in the Southern States nor in many places in the Central and Western States in competition with those grown near the Lakes, as the period of harvesting is too brief and other hazards of the crop are too great. Pea packing is rapidly increasing in Wisconsin and Michigan, because of favorable climatic conditions for production.

\section{PRODUCTION OF PEAS ESPECIALLY FOR CANNING.}

It is said that the different seed firms list about 300 varieties of garden peas, or at least give that many names. The varieties used by most canners are Alaska and Little Gem for the early or smooth varieties, and Horseford's Market-Garden, Admirals, and Advancers for the late or wrinkled varieties. The smooth varieties are not as sweet as the wrinkled.

It would seem as though much improvement might be made in peas through breeding and selection for increased sugar content, fine 
texture, pleasing flavors, and smaller peas. These are qualities especially sought by the trade. To simulate a greater sugar content, sugar is added to the liquor, but the other requirements can only be obtained by proper growth. The possibility of developing a plant with greater resistance to climatic changes, especially heat, and of lengthening the season of derelopment are also worthy of special study.

\section{TIME AND MANNER OF HARVESTING.}

In Indiana, Illinois, Ohio, and States of similar climatic conditions the period of harvesting for the factory is less than twenty days, and seed will not mature to advantage on account of weevils. In Michigan and Wisconsin the harvest period is from six to eight weeks, and the seed readily matures. Ninety per cent of all the pea seed for planting is produced in northern Michigan. The irrigation systems in Colorado and Utah have opened up possibilities in pea growing, the extent of which is not known at this time.

The aerange dates for harerstiug pros for a series of years.

\begin{tabular}{|c|c|c|c|}
\hline state. & Date. & State. & Date. \\
\hline 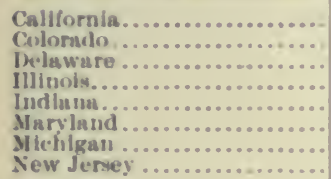 & $\begin{array}{l}\text { May } 30 \text { to June } 20 \\
\text { June } 15 \text { to Ang. } 15 \\
\text { June } 1 \text { to Jume } 30 \\
\text { June } 10 \text { to July } 14 \\
\text { Jume } 5 \text { to July } 10 \\
\text { May } 25 \text { to July } 1 \\
\text { June } 15 \text { to Aug. } 10 \\
\text { June } 1 \text { to July } 8\end{array}$ & 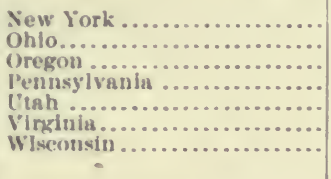 & $\begin{array}{l}\text { June } 15 \text { to Aug. } 1 \\
\text { June } 1 \text { to July } 10 \\
\text { June } 10 \text { to July } 30 \\
\text { June } 1 \text { to July } 1 \\
\text { June } 10 \text { to July } 15 \\
\text { May } 20 \text { to June } 10 \\
\text { June } 15 \text { to Aug. } 10\end{array}$ \\
\hline
\end{tabular}

A longer harveting period in the Northern States is possible because successive plantings can be made of the same varieties as well as of early and late varieties. In the more southern areas the crops are too liable to mature at one time-late-sown peas as early as the first sown-thereby overcrowding the factory.

Peas were formerly gathered by hand. Five pods usually form upon each vine, and the lowest is only about 10 inches above the ground. This part of the work was, therefore, very slow and laborious, and required an amount of help available to but few factories. At present there is only one large factory known to the writer employing hand labor in the picking of the peas. It requires about two thousand pickers to keep a large factory in operation, and adds a cost of about 1.5 to 2 cents to each can.

The method in general use is to cut the vines with a mowing machine, or, if any are exceptionally erect, to use the self-rake reaper. If the mowing machine be used, then it must be followed immediately by men with forks to bunch the peas in order to prevent trampling by the horses, and to put them in condition for easy loading. Within 
the past year or two special attachments have been devised to be connected to the mowing machine for the purpose of bunching and delivering to one side. The cutting is usually done early in the morning, and only such part of the field is cut as can be delivered promptly to the viner. The object is to prevent any heating of the vines or any drying. The vines are loaded upon wagons, like hay, and hauled to the vining machines.

\section{GRADING AND VALUATION OF CROP.}

The basis on which peas are paid for varies greatly at the different factories. Many pay a flat price-so much per bushel or hundred pounds of shelled peas. When this plan is pursued it is advantageous to the factory to insist on the peas being delivered as young as it is possible to use them in order to get the maximum amount of small

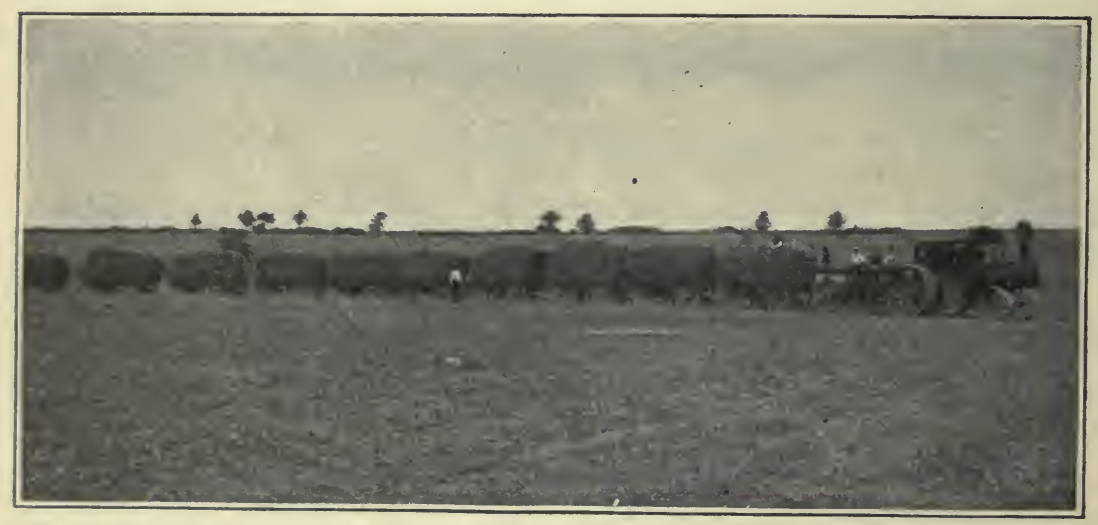

Fig. 1.-Hauling peas at a Wisconsin pea-canning factory.

peas, but it is to the farmer's advantage to delay hauling them in order to get an increase in growth and weight. Such a method is not fair to either factory or producer, neither is it fair to the different producers, one with a first-class load and another with an overripe load.

A second method is to have a scale of prices for two or three grades of peas. The rating of any given load is made by an expert and is a matter of judgment. The appearance of the vines, the size of the peas, the hardness to the sense of touch when squeezed between the fingers, and sometimes the taste are the factors which guide in the decision. Such a method is manifestly better than a flat rate of so much per bushel, but it is not nearly so accurate as could be desired and is also subject to personal bias.

A third method is to pay two or more prices, according to the percentage of peas of a given size. A half-gallon measure of peas 
is taken out of a given load and poured into a box having a bottom perforated with No. 3 holes. If, as the result of shaking, one-half or more of the peas pass through the sieve the highest price is paid; if less than one-half of the peas pass through the sieve and they are fairly soft the second price is paid; if the peas be overripe or hard the lowest price is paid. This method is used by a number of factories and, although not perfect, is an improvement over the other two.

I fourth method is to take a sample from each load during the thrashing and run it through the grader. The sample usually weighs 10 pounds, and the screens in the grader correspond to those used in the factory. The weights of the five grades are taken separately and the price is established upon the percentage of the different sizes of peas. Some factories modify this procedure slightly by rating Nos. 1 and 2 together and Nos. 4 and 5 together, thus making three grades in size as the basis for payment. The greater the percentage of the smaller sizes of peas, the higher the price paid for a bushel. This methor seems the fairest of those now in general use.

The fifth method for payment is based upon quality, rather than upon size, as in three of the methods described, in which it is assumed that small size is associated with immaturity and tenderness, an assumption which is not always in accordance with facts. Large peas may be as soft and tender as the small ones, and small peas may be as hard as those that are overripe. 'This method consists in taking a few vines as a sample from each load, shelling the peas and placing them in a cylinder which has a perforated bottom and is suspended in a salt solution. If the peas are young and tender a large percentage will float in a weak brine. If they are older or second grade they will sink in a light solution, but will float in a heavier'one. If old, hard, or overripe they will sink in the heavier solution. The density of these solutions is varied within narrow limits for the early and late varieties of peas, and is discussed in more detail under grading in the factory (page 13 ).

This method is expeditious, and experience has shown that it is as nearly accurate in practice as the fourth method of grading based on size. The ideal grading system should be based on a combination of size and weight.

\section{FACTORY OPERATIONS.}

VINING OR TIIRASHING.

The separation of the peas from the pods and vines is accomplished by a single operation. The viner is an ingenious though simple piece of mechanism, consisting of an outer cylinder having perforations of such size that peas will pass readily through, but which will retain the pods and vines, and an inner cylinder upon 
which there are paddles or beaters. The outer cylinder is made to revolve slowly in one direction and the inner one at a high rate of speed in the opposite direction. The vines are fed in at one end of the cylinder and are carried up by the slower-moving outer. cylinder until they fall off, and in so doing strike the paddles upon the rapidly revolving inner cylinder. The impact of the paddle causes the pod to break open and the peas to be thrown out. The process is repeated again and again as the vines work from one end of the crlinder to the other. The peas are discharged through the perforations of the outer cylinder and the vines at the opposite end. The work is done thoroughly and the peas are not bruised or crushed by the operation, as might be expected. As a further aid in separating the smaller bits of stems, leares, etc., the peas fall from the cylinder upon a moving web placed at such an angle that the peas will readily roll down into the receiver, while the flat leaves and other particles which will not roll will be carried off.

The rining machines are supplied to the different factories upon a royalty basis, the charge being 3 cents per dozen cans for all shelled peas put up at the factory. These machines are large and, as a rule, are set in batteries at the factory instead of being taken to the fields. $A$ few of the very large factories have established vining stations at varying distances from the factory and bring in the shelled peas by wagon, automobile, or rail. This practice requires rapid handling, as the peas will heat much more quickly after than before being shelled. A large saving in the hauling of vines is effected, and the injury to the peas is probably not greater than would occur in letting the vines wait. These viners were formerly fed by hand, but recently a mechanical feeder has been devised so that the vines are pitched off the load and the machine completes the work. An automatic weighing device has also been added to take the place of the pea collector and weigher, and conveyors are used to carry all vines to the stack or silos so that the actual hand work is reduced to a minimum.

Shelled peas which are hauled to the factory must be kept in thin layers rather than in bulk. The best carrier seems to be a box about 6 inches deep having a raised wire bottom made like that of a berry box. The layer of peas is only about 4 inches thick and is well ventilated. The boxes or crates, no matter how constructed, must be sterilized with steam and rinsed with scalding water each day or they will become infected with germs which will cause spoilage.

WASHING.

The first operation through which the peas pass after being weighed from the viner is that of washing. This is accomplished in what is known as the squirrel cage. which is a wire cylinder about 3 feet in diameter and 12 feet long. The cylinder is set on a slight in- 
cline so that when the peas are admitted at one end they will tend to roll to the other as the cylinder revolves. On the inside is a perforated pipe that sprays a stream of water upon the peas, which insures their being well washed provided the spray has some force. When the weather is very warm and the peas accumulate more rapidly than they can be passed through the filler, it may be necessary to wash the shelled peas in cold water every few hours in order to prevent fermentation. The washing should be thorough not only to remove all dirt, but also the mucous substance, thus insuring a clearer liquor. (See fig. 2.)

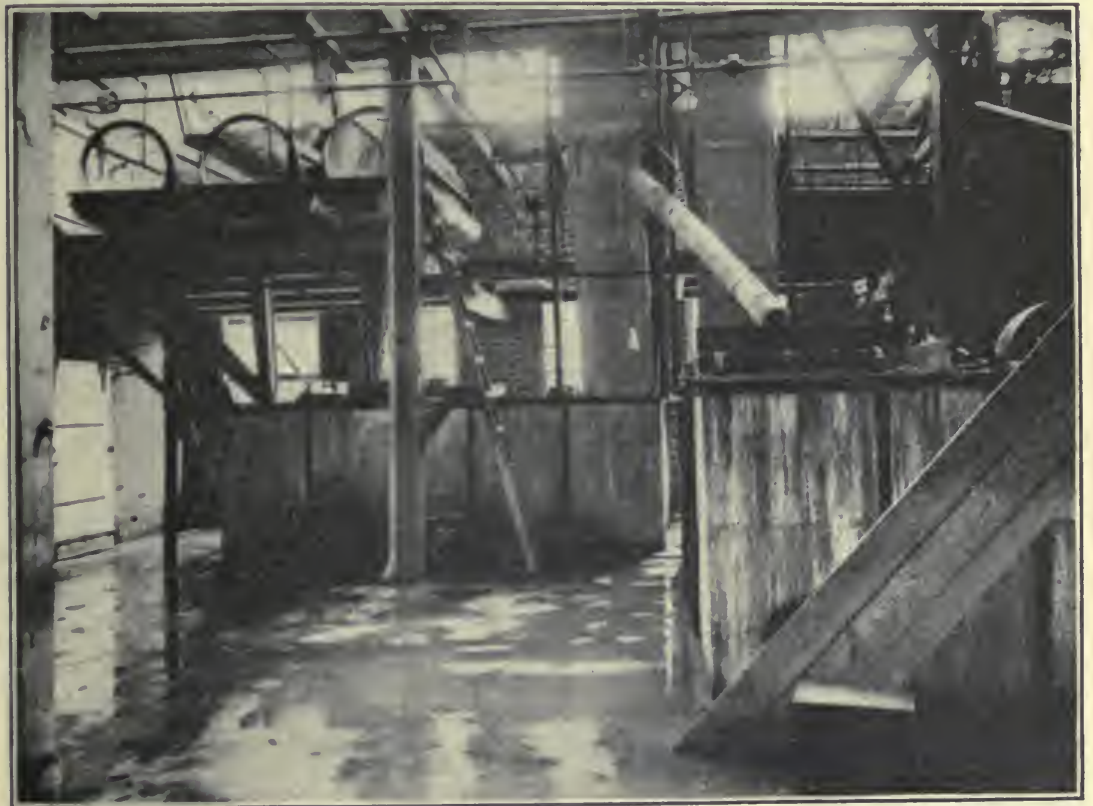

Fio. 2.-Interlor of cannery showing squirrel cages for washing peas and the brine tanks where they are graded according to quality.

(iR.IDING FOIR QUALITY.

After the peas pass through the washer, they should be graded according to the degree of maturity or hardness. This is accomplished by passing them through tanks containing salt solutions of different densities. It has been found that the young tender peas will float in a salt solution somewhat heavier than water and those more mature will sink, while the very mature peas will sink in a heavy salt solution. Peas, therefore, may be sorted very readily into different grades according to their density by using different strengths of salt water. In practice three grades have been made. The first grade consists of all peas which will float in a solution having a specific gravity of 1.040. The second grade consists of those peas which will sink in a 
solution of this density but which will float in a solution having a specific gravity of 1.070 . The third grade consists of the peas which will sink in the latter solution. Figures 3 and 4 show how the three grades of peas are separated by this means. A machine has been devised to remove the peas from the top and bottom of these solutions so that their separation is automatic and continuous.

The principle involved in the separation of peas into grades for quality is not new, having long been applied to the selection of seerls.

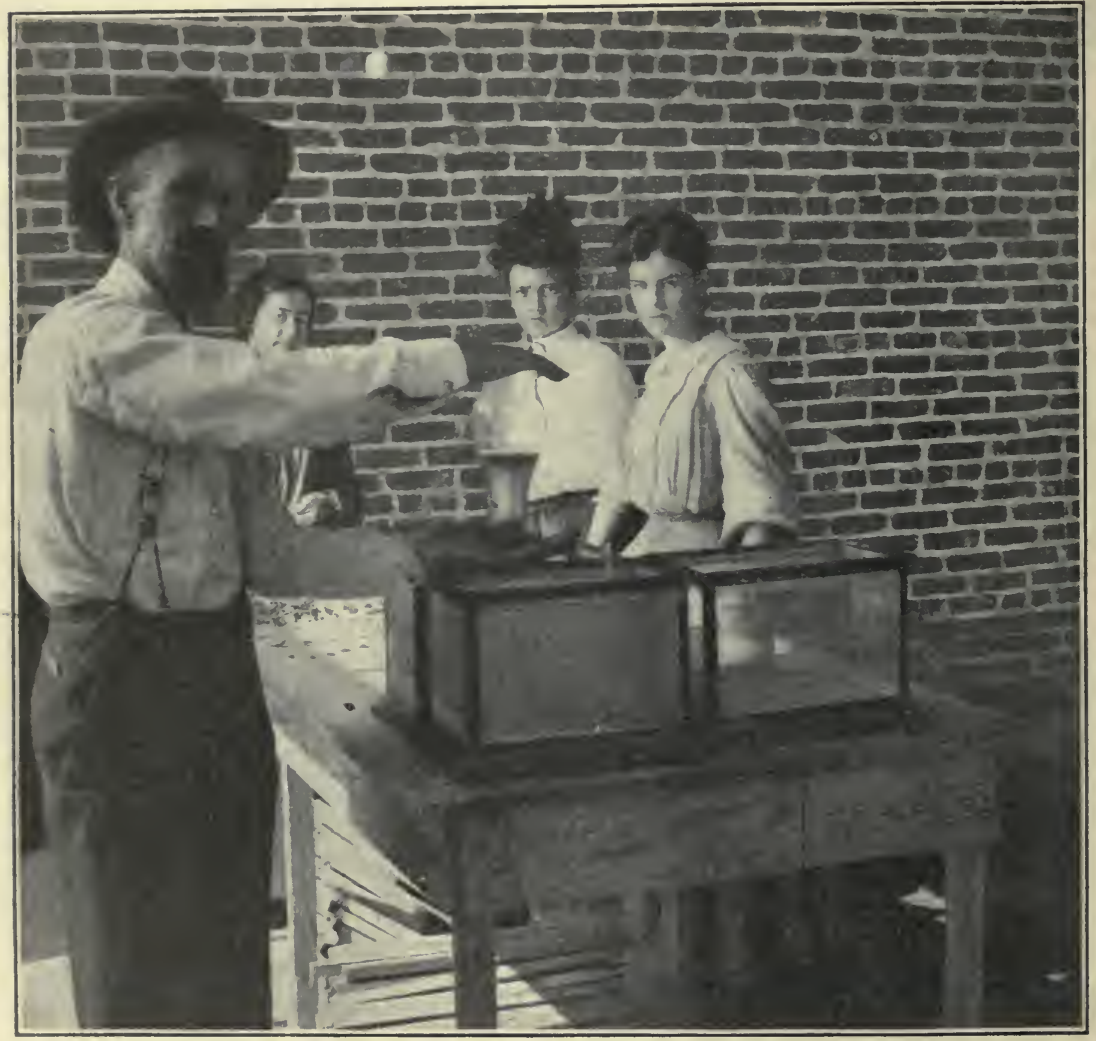

FIG. 3.-Testing the peas in a salt solution for quality.

It was tried for grading peas for several years without success, because solutions having the proper density were not obtained and the necessary working apparatus was not available. On May 27, 1894, a patent was granted on a device for grading peas, which has since been improved so as to work very well.

-The grading of peas for quality is as sharp and clear as that for size. The lightest weight peas are the finest, being even in quality, succulent, and tender. The heaviest peas are the poorest, being uneven in quality, hard, overripe, and of bad color. The middle- 
weight peas are good, but harder than the first grade, of darker color: and not so uniform. These differences are most apparent before the canning is done, though they are readily distinguishable in the can, and also show on chemical examination.

In any load of peas there must be some plants more mature than others, and as a consequence, some hard peas will be mixed with the tender ones. Every effort is made to cut the peas at nearly the same state of maturity, but no field will ripen perfectly evenly. If the
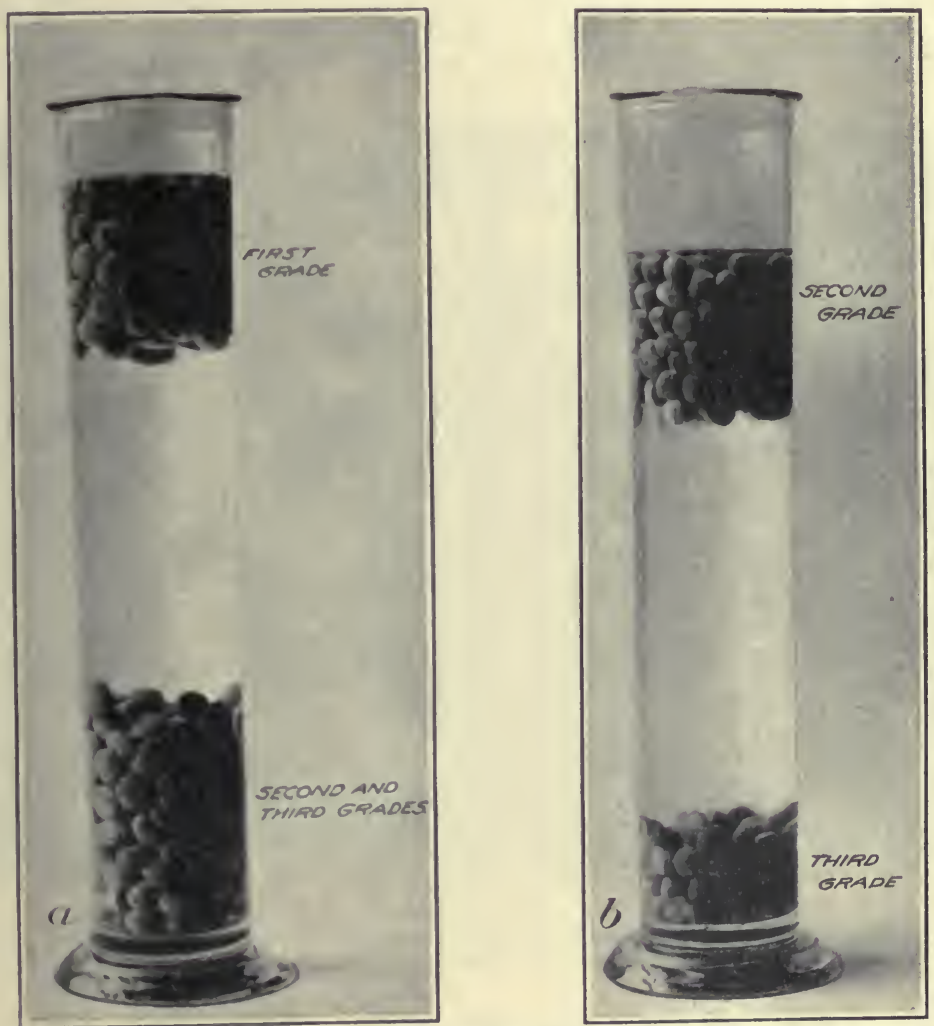

Fig. 4.-Separation of three grades of peas by suspension in salt solutions : (a) Weak salt brine (sp. gr. 1.040): (b) strong salt brine (sp. gr. 1.070).

peas be produced by a hundred farmers, the differences will be accentuated. In localities where the peas mature slowly, the differences will be less marked than where they mature rapidly. Under any conditions there will be some differences in quality, and under unfavorable conditions the percentage of poor peas may be very high. Separation for quality is so well effected by the specific gravity grader that it undoubtedly will receive a recognition equal to that given the sizing machine. 
According to an Indiana factory, in which the quality system of grading has-been developed, peas rated good and poor upon the wagon gave the following results after passing through the grader.

Quality grading compared with wagon tests.

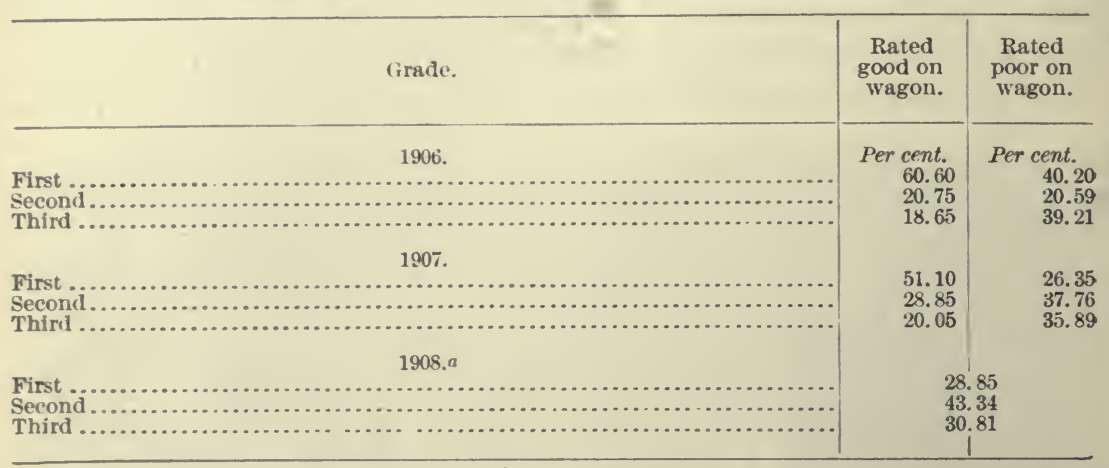

a Whole crop rated by grader in this year.

Had the specific-gravity system not been in use the output of firstclass peas would have been much smaller and that of second and third grades correspondingly increased. The trade permits a small percentage of hard and off-size peas in the first grade, but with this system these "off" peas are very few. The characteristics of the different grades will be considered again under the finished product.

A chemical examination of peas graded for quality as well as for size gave results as shown in the following table:

Chemical examination of peas graded for size and quality.

[Analyses made In the Division of Foods, Bureau of Chemistry.]

\begin{tabular}{|c|c|c|c|c|c|c|c|c|c|}
\hline Grade. & $\begin{array}{l}\text { Total } \\
\text { solids. }\end{array}$ & Ash. & $\begin{array}{l}\text { Crude } \\
\text { protein. }\end{array}$ & $\begin{array}{l}\text { Crude } \\
\text { fiber. }\end{array}$ & $\begin{array}{l}\text { Pento- } \\
\text { sans. }\end{array}$ & Starch. & Sucrose. & $\begin{array}{l}\text { Redueing } \\
\text { sugar. }\end{array}$ & $\begin{array}{l}\text { Undeter- } \\
\text { mined. }\end{array}$ \\
\hline $\begin{array}{l}\text { Petits pols: } \\
\text { First......... } \\
\text { Second ....... } \\
\text { Third....... } \\
\text { Sifter: }\end{array}$ & $\begin{array}{l}14.23 \\
18.80 \\
18.44\end{array}$ & $\begin{array}{l}1.03 \\
1.78 \\
1.82\end{array}$ & $\begin{array}{l}3.44 \\
4.19 \\
4.41\end{array}$ & $\begin{array}{l}1.68 \\
1.84 \\
2.28\end{array}$ & $\begin{array}{r}0.75 \\
.92 \\
.94\end{array}$ & $\begin{array}{l}5.57 \\
8.53 \\
8.53\end{array}$ & $\begin{array}{c}0.72 \\
.93 \\
.817\end{array}$ & $\begin{array}{r}0.00 \\
.00 \\
.00\end{array}$ & $\begin{array}{c}1.04 \\
.61 \\
.357\end{array}$ \\
\hline $\begin{array}{l}\text { First......... } \\
\text { Second ....... } \\
\text { Third........ }\end{array}$ & $\begin{array}{l}22.06 \\
24.32 \\
27.74\end{array}$ & $\begin{array}{l}1.36 \\
1.04 \\
1.37\end{array}$ & $\begin{array}{l}5.31 \\
5.69 \\
5.63\end{array}$ & $\begin{array}{l}2.21 \\
2.05 \\
2.18\end{array}$ & $\begin{array}{r}.96 \\
1.01 \\
1.50\end{array}$ & $\begin{array}{l}10.23 \\
11.52 \\
13.52\end{array}$ & $\begin{array}{l}.987 \\
.57 \\
.48\end{array}$ & $\begin{array}{l}.00 \\
.00 \\
.00\end{array}$ & $\begin{array}{l}1.012 \\
2.44 \\
3.06\end{array}$ \\
\hline $\begin{array}{l}\text { Marrowfat: } \\
\text { First......... } \\
\text { Second ....... } \\
\text { Third....... }\end{array}$ & $\begin{array}{l}22.22 \\
24.10 \\
27.15\end{array}$ & $\begin{array}{l}1.02 \\
1.30 \\
2.03\end{array}$ & $\begin{array}{l}5.13 \\
6.69 \\
5.94\end{array}$ & $\begin{array}{l}2.18 \\
2.55 \\
2.00\end{array}$ & $\begin{array}{r}.98 \\
1.55 \\
1.27\end{array}$ & $\begin{array}{r}10.48 \\
8.77 \\
12.91\end{array}$ & $\begin{array}{l}.94 \\
.636 \\
.361\end{array}$ & $\begin{array}{l}.00 \\
.00 \\
.00\end{array}$ & $\begin{array}{l}1.49 \\
2.604 \\
2.639\end{array}$ \\
\hline
\end{tabular}

The table shows more total solids and higher protein and starch content in the third-grade goods. This might be expected, as the third grade represents the more mature product. If canned peas were purchased for their nutritive properties only, then the third 
grade would be the preferable one to buy, but they are usually selected for their delicacy and flavor, which are found in the highest. degree in the youngest and tenderest peas, or the first grade.

GRIDING FOR SIZE.

The grading for size is a very simple matter. The peas are passed over sieves, or into a revolving cylinder having four sections with perforations of different sizes. The perforations in the first sieve or section measure nine thirty-seconds of an inch in diameter. The peas which pass through this size opening are known as No. 1, or

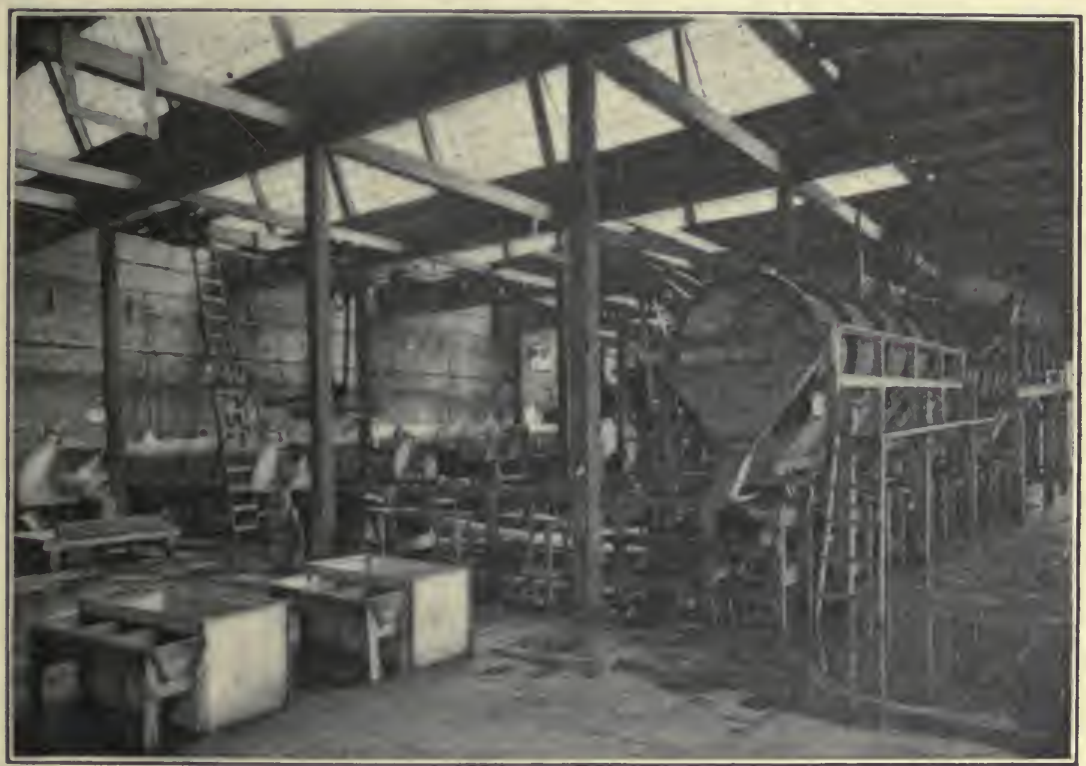

Fit: 5.-.I molern sanitary pea-canning plant. The large cylinders on the right are the graders for size. Below them and extending out into the room are the picking belts. On the left are the cyllnder blanchers. The roof shows the sawtooth lighting system, and the floor is of concrete for flushing.

"petits pois." The next size of perforation is ten thirty-seconds of an inch in diameter, and the peas passing through are known as No. 2 , "extra sifted," or "extra fins." The third size of perforation is eleven thirty-seconds of an inch, and the peas which pass through are known as No. 3, "sifted," or "fins." The last size is twelve thirty-seconds of an inch, and the peas which pass through are known as No. 4, or "early June" peas. The peas which are too large to pass through this sieve go over the end and are known as No. 5, or " marrow fats." Some packers add one more sieve for late peas, with perforations thirteen thirty-seconds of an inch in diameter for the No. 5, and those which pass over this sieve are called No. 6, 
or "telephone peas." The sizes of these perforations are standard and in general use. Some packers have attempted to make sizes of their own by reaming out the holes, while others do not use all four sieves, but group two sizes together; and some peas are ungraded.

These sizes are so nearly standard for all pea packing that they should be adhered to in the labeling. The term "early June" peas as now used applies to a certain size and not to the season at which the peas are picked, and the size larger, or " marrowfat," should not be labeled "early June." "Extra early June" or "May pickings" is not a proper designation for sifted peas. It is evident that the standard terms used to designate size should be employed in labeling if the proper meaning is to be conveyed to the purchaser. Commercially, almost any size of pea may be found to be selling as "early June" in the cheaper grades. The more expensive peas are usually sold true to name, though it is not unusual to get smaller peas in the high grades than is indicated upon the label. The terms "early June," "May pickings," "extra early June," and others of that character could be advantageously supplanted by names more distinctive of size, as the present terms conflict with the requirements of the food and drugs act as to labeling, unless the product be actually packed at the time indicated.

The percentage of peas which go into the different sizes will vary considerably with the time of harvesting, the variety, and the season. One of the large factories furnishes the following figures upon the crops for 1906 and $190 \pi$ :

Percentage of different sizes in the crops of two years.

\begin{tabular}{|c|c|c|c|}
\hline & Size. & 1906. & 1907. \\
\hline $\begin{array}{l}\text { 1. Petits pois... } \\
\text { 2. Extra sifted. } \\
\text { 3. Sifted } \\
\text { 4. Early June. } \\
\text { 5. Marrowfat. }\end{array}$ & 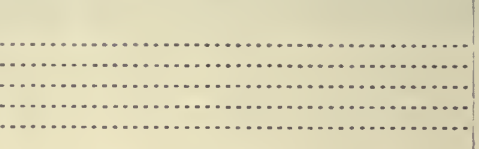 & $\begin{array}{r}\text { Per cent. } \\
4.00 \\
7.50 \\
30.30 \\
50.20 \\
8.00\end{array}$ & $\begin{array}{r}\text { Per cent. } \\
7.60 \\
12.20 \\
34.70 \\
28.10 \\
17.40\end{array}$ \\
\hline
\end{tabular}

It is not known how these figures will compare with the grading for the entire country, as this is a matter which canners do not make public.

HAND PICKING.

After the peas have been graded into sizes they are usually run in thin layers over slowly moving belts, so that pieces of foreign material, broken, fully matured, and defective peas may be seen easily and removed. Low-grade peas are not so carefully picked over.

In the section of the country where Canada thistles are abundant, their separation is a difficult problem, as the thistle top is about the 
same size as the pea, and only the very large ones are removed by the graders. During the last season experiments were made in removing the thistle tops by the specific gravity system, and it was found that more than 90 per cent of them would float in a light brine (having a density of 1.020 ), while only a small percentage of the peas floated in such a solution. It is evident, therefore, that instead of employing hundreds of girls to perform this work, more than 90 per cent of the tops could be collected in less than 10 per cent of the peas. The reduction of the tedious hand labor by such a method is apparent. These tests were made too near the close of the season to be completed, but sufficient work was done to demonstrate the correctness of the principle. The work can also be very materially reduced by separating the thistles from the vines at the vining machine.

\section{BIANCHING.}

There are two objects in blanching peas: (1) To remove the mucous substance from the outside and a part of the green coloring matter, so as to have a clear liquor in the can; and (2) to drive water into the peas so that all will be tender.

In the young, juicy pea, the water content is at its maximum, so that the cleaning of the surface is all that is necessary. The time required for blanching is from one-half to one minute for No. 1 and No. 2, or "petits pois" and "extra sifted;" one and a half minutes for No. 3, or "sifted;" two minutes for No. 4, or "early June;" and two and one-half minutes for No. 5 , or "marrowfat" peas. To get the best results, peas which are very old and hard will need a blanch approximately five times as long as young peas of the corresponding grade, while those in the intermediate stages will require a blanch proportional to their development.

It is evident, therefore, that among peas that are good, but ungraded as to quality, there will be a greater or less number which will be hard because of under blanching, and some above size because of swelling during the blanching and after processing. There is no part of the work of canning peas which requires so much judgment as that of blanching if the best quality of goods is to be obtained. Much of the very cheap goods upon the market are made so because of following "rule of thumb" methods in this department. The division of peas into grades for quality as well as for size will simplify somewhat the problem as to the length of time that blanching should be continued, but not to the point of making the position of blancher one of secondary importance in the canning factory.

Experiments were made to determine the effect of varying periods of blanching on the different sizes and grades of peas and the influence exerted on swelling, tenderness, color of the liquor, and fill of 
the can. While the primary object was to determine the relation of blanching to spoilage, the secondary effect an the commercial grading was evident.

Young peas will stand either a long or short blanch better than old ones. The effect upon the increase in size was determined by running the peas over the same size screens before and after blanching, and noting the percentage which did not pass through. It was found that after a ten-minute blanch the percentage which showed an increase in size was as follows:

Percentage of peas increased in size by blanching for ten minutes.

\begin{tabular}{|c|c|c|c|}
\hline size of pens. & Grade 1. & Grade 2. & Grade 3. \\
\hline 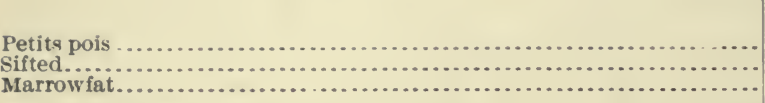 & $\begin{array}{r}\text { Per cent. } \\
28 \\
26 \\
24\end{array}$ & $\begin{array}{r}\text { Per cent. } \\
45 \\
42 \\
42\end{array}$ & $\begin{array}{r}\text { Per cent. } \\
82 \\
56 \\
68\end{array}$ \\
\hline
\end{tabular}

The increase in size was much greater in grades 2 and 3 than in grade 1. The experiments with the one-minute blanch and the fiveminute blanch were not made upon complete sets, but the results obtained indicated a similar change, though it was less marked.

The peas were filled into the can so as to give a uniform weight, and water was added without salt or sugar, to give a total of 660 grams. After processing it was found that of those given the short blanch, the peas in grade 1 had taken up but little of the liquor, and those in grades 2 and 3 , particularly the latter, had taken up so much of the water as to leave an insufficient amount to cover the peas in the can.

The appearance of the liquor was best on grade 1 for the one-minute blanch, and good for the five-minute and ten-minute blanches; on grade 2 it was best for the five-minute blanch, and on grade 3 best for the ten-minute blanch. The liquor on grade 1 was clear, on grade 2 , cloudy but thin, and on grade 3, thick and starchy. The peas in grade 3 for the one-minute blanch had formed a solid mass with the liquor so that half of the peas would not fall out when the can was inverted.

Tender peas which are over-blanched, soften, break open, and discharge free starch grains so as to make a muddy liquor, and if in great excess, the liquor in the bottom of the can becomes pasty. Old peas which are under-blanched remain hard and unpalatable after processing, or, if given a hard process, they will take up all the liquor in the can and become a more or less thickened mass. Such peas never have clear liquor. If the tender and hard peas be mixed, and the blanching be set for the young peas, the older ones are not well done; 
if set for the older peas, the tender ones are overdone. It follows, therefore, that to get good results requires much judgment, and a system of blanching tests could possibly be worked out to advantage.

The operation of blanching peas is of comparatively recent introluction in the pea-packing process and at first was thought to be an unnecessary step. When the liquor was unattractive, the peas were placed in loose bags or perforated buckets and suspended in hot water for a short time, after which the water was drained off. From this practice the operation of blanching developed, and at present a number of blanching derices are on the market. Those seen in operation are of two types. In the older one the peas are held in a wire basket which is suspended in a trough of hot water. The trough is usually long, and mechanical devices are arranged to carry the baskets through at such a speed as will insure their being given a certain length of time for the different sizes. These tanks vary from 20 to 80 feet in length. The second type of blancher is that of the continnous washer. A cylinder is made to revolve in a shallow tank of water and if run at a given speed, the peas will be delivered at the opposite end in a giren time. Some of these cylinders are sectioned in order to have cleaner water as the blanching progresses. The hot water is admitted at one end and the waste escapes from the opposite end. The raw peas and the water enter opposite ends of the trough so that the clean peas do not come in contact with the dirty water. From a sanitary standpoint. this is the better type of apparatus, though in practice, the trough blanchers are probably the more economical, but not so cleanly.

FII.ING THE ('ANS.

When the peas leave the blancher, they are sometimes washed, and this is desirable in order to insure a clear liquor, especially if the peas have been blanched in wire baskets suspended in a tank of water.

The peas are filled into the cans by special machines, although in very small factories this may be done by hand. The modern machines do the work with a fair degree of aceuracy, insuring a uniform quantity in each can, then adding liquor to fill, so that the caps will just go on. Figure 6 shows a battery of filling machines into which the peas are delivered directly from the blanchers.

I can is said to be well filled when the contents are within threeeighths inch of the eap and the peas are just covered with liquor. Peas of excellent quality when covered to too great a depth with liquor deteriorate in appearance as can be determined by inserting a spoon and raising the peas gently but without appreciably disturbing the liquor. On the other hand, if there is not sufficient liquor to cover the peas, they are not generally attractive, and if very short 
on liquor, they become pasty. It is important, therefore, to use just enough liquor to cover the peas.

The No. 2 can generally used is popularly supposed to mean a 2-pound can, and is often so billed and referred to in market reports, but it does not hold 2 pounds and should be given its proper designation. The a verage fill of a can is such that after processing there will be 14 ounces of peas ( 400 grams) and $\tau_{4} \frac{1}{4}$ ounces (200 grams) of liquor. The can weighs 100 grams, making a total of 700 grams or 25 ounces. Any very marked deviation from these figures in the direction of reducing the proportion of peas would evidently be an

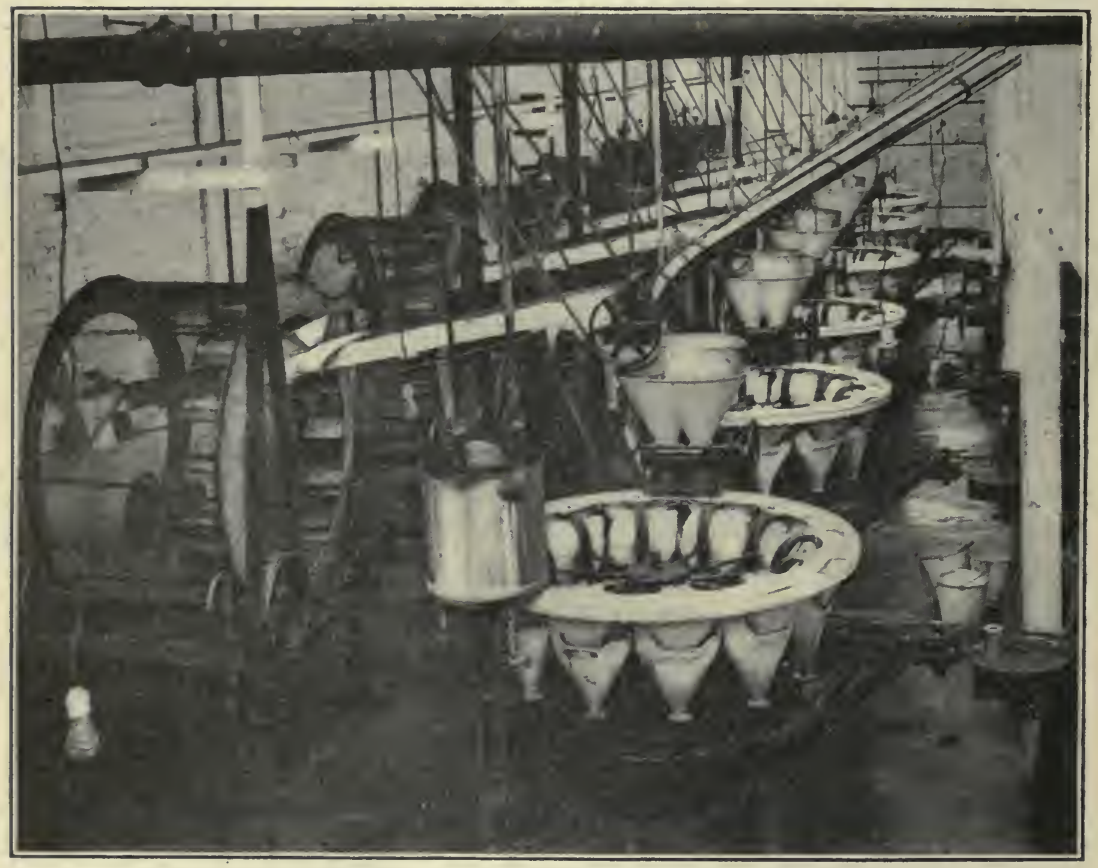

FIG. 6. - A battery of filling machines.

adulteration.with water, while any considerable increase in the proportion of peas would result in dryness. Cans containing only 11 or 12 ounces of peas are evidently short weight, though a customer can not reasonably demand more than 15 ounces as a maximum and expect a good appearance.

A can of marrowfat or telephone peas will not weigh as much by about three-fourths ounce ( 20 grams) as a can of the smaller-sized peas if the fill be the same. The "sifted" pea, or No. 3 size, is the heaviest in the commercial grading. The "extra sifted" and the "petits pois" are the most expensive to the canner, and the tendency is to cut slightly in the weight, usually about three-fourths of an 
ounce, although it is not uncommon to get cans from $1 \frac{1}{2}$ to 2 ounces short on peas and correspondingly overweight on liquor.

The amount of peas put in a can will depend upon the grade, the time given in the blanch, and the length of the process. The better the grade of pea the greater the quantity which will go into the can, and these will be least affected by either blanching or processing, while the poorest grade of peas is affected the most. In filling a can with good peas, an allowance of less than one-fourth of the space in the can is made for swelling as a result of processing, and for poor peas an allowance of more than one-half is made, so that the volume of peas used in the former case is about three-fourths, and in the latter about one-half the volume required in the finished product.

Experiments made to determine the increase in the weight of peas as the result of processing showed that, given the same process, the first or best grade increased from 8 to 11 per cent, the second or intermediate grade from 16 to 21 per cent, and the third grade from 24 to 33 per cent. There was also some variation in the increase in weight with the different sizes of peas, the "petits pois" showing the greatest increase in the poorest grade. These experiments were limited to the conditions present somewhat late in the season and are not complete, but only indicative in a general way of the changes which take place.

The following table, based on the examination of a number of cans filled and brined by machine, shows approximately the character of the changes, some variation in the figures being due to the use of volume instead of weight as the unit in filling:

liffect of processing on the size of different grade's of peas.

I.HTITS I'OIS (NO. 11.

\begin{tabular}{|c|c|c|c|c|c|c|c|c|}
\hline \multirow{2}{*}{ Grade. } & \multirow{2}{*}{$\begin{array}{c}\text { Total } \\
\text { weight. } \\
\text { grams. }\end{array}$} & \multicolumn{3}{|c|}{ Welght (grams). } & \multirow{2}{*}{$\begin{array}{l}\text { Charucter of } \\
\text { brine. }\end{array}$} & \multirow{2}{*}{ Condition of pers. } & \multicolumn{2}{|c|}{$\begin{array}{l}\text { Size after process- } \\
\text { ing. }\end{array}$} \\
\hline & & Can. & Brine. & Peas. & & & $\begin{array}{l}\text { Grams un- } \\
\text { changed. }\end{array}$ & $\begin{array}{l}\text { Grams in- } \\
\text { creased. }\end{array}$ \\
\hline $\begin{array}{l}\text { First.... } \\
\text { Second . } \\
\text { Third... }\end{array}$ & $\begin{array}{l}690 \\
690 \\
675\end{array}$ & $\begin{array}{l}100 \\
100 \\
100\end{array}$ & $\begin{array}{l}230 \\
205 \\
155\end{array}$ & $\begin{array}{l}360 \\
385 \\
420\end{array}$ & $\begin{array}{l}\text { Clear .......... } \\
\text { Cloudy ........ } \\
\text { Thlek ....... }\end{array}$ & $\begin{array}{l}\text { Fine } \ldots \ldots \ldots \ldots \\
\text { Fair } \ldots \ldots \ldots \ldots \ldots \\
\text { Poor } \ldots \ldots \ldots \ldots \ldots\end{array}$ & $\begin{array}{l}215 \\
150 \\
120\end{array}$ & $\begin{array}{l}145 \\
210 \\
300\end{array}$ \\
\hline
\end{tabular}

FXTR.। SIFTED OIR "FXTIR.I FINS" (XO) :

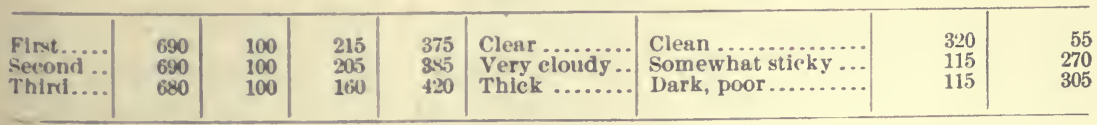

SIFTFD OR "FINS" (NO. 3).

\begin{tabular}{|c|c|c|c|c|c|c|c|c|}
\hline $\begin{array}{l}\text { First..... } \\
\text { Serond .. } \\
\text { Third... }\end{array}$ & $\begin{array}{l}690 \\
690 \\
675\end{array}$ & $\begin{array}{l}100 \\
100 \\
100\end{array}$ & $\begin{array}{l}200 \\
195 \\
165\end{array}$ & $\begin{array}{l}390 \\
395 \\
410\end{array}$ & $\begin{array}{l}\text { Clear } \ldots . . . \ldots . \\
\text { Cloudy .......... } \\
\text { Starchy...... }\end{array}$ & $\begin{array}{l}\text { Clean .............. } \\
\text { Poor and cloudy.... } \\
\text { Peas sticky.......... }\end{array}$ & $\begin{array}{l}335 \\
205 \\
185\end{array}$ & $\begin{array}{r}55 \\
190 \\
225\end{array}$ \\
\hline
\end{tabular}


Effect of processing on the size of different grades of peas-Continued.

EARLY JUNE (NO. 4);

\begin{tabular}{|c|c|c|c|c|c|c|c|c|}
\hline \multirow{2}{*}{ Grade. } & \multirow{2}{*}{$\begin{array}{c}\text { Total } \\
\text { weight, } \\
\text { grams. }\end{array}$} & \multicolumn{3}{|c|}{ Weight (grams). } & \multirow{2}{*}{$\begin{array}{c}\text { Character of } \\
\text { brine. }\end{array}$} & \multirow{2}{*}{ Condition of peas. } & \multicolumn{2}{|c|}{$\begin{array}{l}\text { Size after process- } \\
\text { ing. }\end{array}$} \\
\hline & & Can. & Brine. & Peas. & & & $\begin{array}{l}\text { Grams un- } \\
\text { changed. }\end{array}$ & $\begin{array}{l}\text { Grams in- } \\
\text { creused. }\end{array}$ \\
\hline $\begin{array}{l}\text { First..... } \\
\text { Second ... } \\
\text { Thiril.... }\end{array}$ & $\begin{array}{l}690 \\
680 \\
675\end{array}$ & $\begin{array}{l}100 \\
100 \\
100\end{array}$ & $\begin{array}{l}205 \\
185 \\
175\end{array}$ & $\begin{array}{l}385 \\
395 \\
400\end{array}$ & $\begin{array}{l}\text { Clear ........... } \\
\text { Thick ........ } \\
\text { Gery sticky... }\end{array}$ & 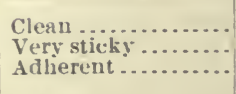 & $\begin{array}{l}295 \\
275 \\
170\end{array}$ & $\begin{array}{r}90 \\
120 \\
320\end{array}$ \\
\hline
\end{tabular}

M.IRROWFAT (NO. 5).

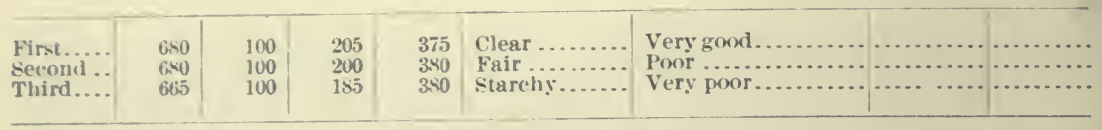

COMPOSITION OF I.IQTOR.

The liquor used on peas is usually composed of water, salt, and sugar. At one time saccharin was used by many packers instead of sugar, but this practice has been almost entirely discontinued. The proportion of salt and sugar used varies greatly with the different packers. The lowest amounts given were 2 pounds of salt and 2 pounds of sugar to 100 gallons of water. The largest quantities used were 40 pounds of sugar and 16 pounds of salt per 100 gallons, while the average seems to be about 10 pounds of salt and 10 of sugar per 100 gallons of water. There is undoubtedly a tendency to reduce the amount of sugar used. and a few canners have left out both salt and sugar in some lots of peas to determine whether there is a inarket for an unseasoned product. The heary sirups are used in the fancy and extra fancy brands of goods, the amount of sugar added to the sirup being often the only difference between the "superlatively good " and the "best." A fairly sweet sirup is sometimes used to give a weak, insipid, sugarless pea some semblance of quality. also to make the smooth pea as sweet as the sweet wrinkled variety. Analyses ${ }^{a}$ of 35 brands of peas purchased in the open market show the sugar content of the liquor to vary between 0.46 and 4.17 per cent. the average being 2.62 per cent. More sugar is found in eastern than in western packed peas, and in the domestic than in the foreign peas.

\section{PROCESSING.}

After being filled the can is passed through the wiping machine, the cap is put on and soldered in the automatic capper. the tipping follows, and then comes the final inspection in the water bath for leaks. At one factory the cans were passed through an exhauster for the double purpose of heating them uniformly and of driving off a certain characteristic odor which is objectionable.

\footnotetext{
a Analyses made by G. Spitzer, Indiana Agricultural Experiment station.
} 
Peas are processed in retorts under pressure, or in a solution of a calcium salt, in order to secure a temperature above that of boiling water. The germs which are found upon and associated with the pea can not be killed at boiling temperature unless it is continued for such a length of time as to ruin the peas. The spores of these germs are supposed to resist any temperature below $240^{\circ} \mathrm{F}$. for twenty minutes. The time and temperature necessary to sterilize peas can not be given with certainty because of the variation in factory practice and conditions which must be taken into account. If all factories handled their material promptly after being cut in the field, allowed no dolays, such as standing on wagons or in piles to ferment, washed the peas well as soon as thrashed, graded them equally well, blanched them according to their needs, siruped and filled the cans the same, tipped the cans at the same temperature, and brought them to the process tank under like conditions, it would be possible to develop a process which might be safe for nearly all localities. Such ideal conditions are not to be found in practice, and hence it is that one factory will employ a process of $240^{\circ} \mathrm{F}$. for twenty minutes and do it successully, while another must double the time before being reasonably successful in preventing spoilage.

The duration of the process should be considered as the length of time during which the eans are submitted to a cooking temperature, and not the length of time they are in the retort. If a retort be filled with crates of cans, it will take a fel minutes for the steam or water to come to a fairly stationary temperature. When steam is used most factories allow from three to five minutes to bring up the temperature, and when water is used from eight to ten minutes. This practice is often followed too closely, not taking into account the fact that some peas are filled and tipped while at a temperature of $180^{\circ} \mathrm{F}$. and others at $100^{\circ} \mathrm{F}$. In the best of the hundred canning factories inspected the most careful attention was given to time and temper:ture of processing. The temperature was raised gradually, continued uniformly, and shut off slowly. The circulation stopcocks were opened and closed to insure a positive temperature at all points, and the valves adjusted to meet any slight change above or below.

For many year's the details of the process were considered a factory secret, and that feeling has not wholly passed away. It is evident that most canners allow a good margin of safety to prevent spoilage. The majority follow the rules indicated by general practice and make little attempt to vary them for particular conditions so as to get the best possible results.

The process given to peas varies considerably in factory practice, the lowest temperature being $230^{\circ} \mathrm{F}$. for from twenty-five to thirty minutes. The rule. however, is to accept $240^{\circ} \mathrm{F}$. as the proper temperature and to vary the time from twenty-five to forty minutes. There are a few who use the short period, but most packer's consider 
it unsafe. The majority are processing from thirty to thirty-five minutes for freshly thrashed, tender peas; from thirty-five to forty minutes for peas allowed to stand overnight in the vines, and fortyfive minutes at $245^{\circ}$ for very old hard peas. As peas are unlike corn and pasty products, and the heat penetrates easily and quickly, it would seem as though these periods give a large margin of safety. The writer processed good peas for ten minutes and for fifteen minutes at $240^{\circ}$ for the purpose of getting spoilage, but got none. Poor peas were processed at $240^{\circ}$ for twenty, twenty-five, thirty, thirty-five, fifty, and fifty-five minutes with a like result. Although these experiments in getting spoilage gave only negative results, no factory is advised to use such a short process.

There was an incidental factor brought out in these experiments which is of some importance to the canners; that is, the effect of length of process upon the liquor content of a can. The peas used in this experiment were of rather poor grade, hard, and starchy, but not worse than may be seen in thousands of cans of standard peas upon the market. The effect of long processing is to cause a gradual decrease in the amount of free liquor in the can and to cause the peas to become sticky and adherent. This effect is shown in the following table :

Effect of variation in time of processing on liquor content of can.

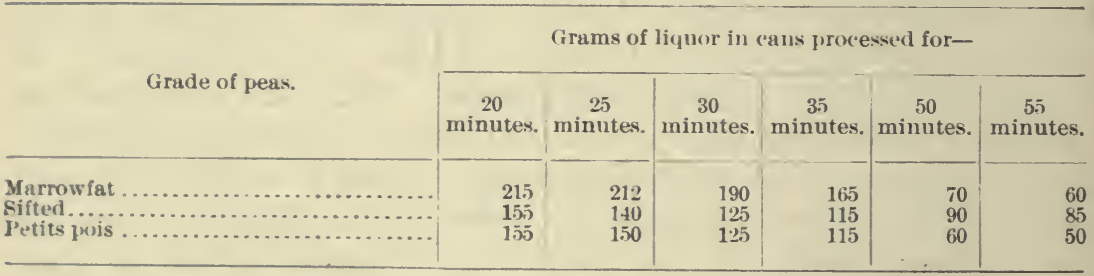

The peas were sufficiently cooked in twenty-five minutes, and at each succeeding step they became thicker and stickier. The contents of the cans processed for fifty and fifty-five minutes adhered so closely that only part would fall from the inverted can. The time given to processing should be sufficient only to sterilize, and the processor should use judgment in every case, giving the shortest time which will be safe and cause the least injury to the goods. The better grade of peas will suffer less injury from long or high process than the poorer grades.

There is some controversy among pea packers as to the best form of heat for obtaining the most attractive product. Some process in dry steam, some in water given the desired temperature, and others in the calcium bath. The adrocates of the water process claim that they secure a clearer liquor and a brighter can. Experiments were made to determine this point, but it was impossible to distinguish cans processed in dry steam slowly heated in the retort from those 
processed in water. Cans heated gradually - that is, by turning the steam on slowly so that it required ten minutes to heat the retorthave a clearer liquor than when the steam is turned on suddenly at full pressure. The very quick heating injures the peas in contact with the can and also causes a blackening inside of the can. As the calcium system is maintained at a high heat, the effect upon the peas is more like that of the quick, dry steam than of the water process. Sterilization can be accomplished with equal certainty by any one of the three methods, the choice depending upon the relative economy and the effect upon the goods.

COOLING THE FINISHED PRODCCT.

Peas should be well cooled as soon as the process is completed. Sterilization is iccomplished by a certain degree of heat applied for a given time. Raising or prolonging the temperature beyond that necessary for sterilization does no more in preventing spoilage, but does break down the peas to a greater or less degree and injures their appearance in the can. The peas, therefore, should be cooled at once to a fairly low temperature in order to get the best results. A comparison of the contents of half a dozen well cooled cans with a like number not cooled will demonstrate conclusively the inferiority of the latter.

There are some packers who turn water into the retort as soon as the steam is turned off, and thus get the best results, but at a large cost. If the peas be lifted out of the retort and placed at once in the cooling tank or under a sprinkler, the cost of cooling will be much lower and the results nearly as good. It is desirable that the peas should be cooled to $100^{\circ}$ or lower if practicable. If the cans are only slightly cooled and are built up in large, solid stacks, those in the (eenter will hold their heat for weeks. If the cans are not well cooled they should be placed in ricks, with spaces between to facilitate cooling. One of the desirable results of quick cooling is that the leaks are found more quickly. The condensing of the steam causes a vacuum pressure of from 6 to 12 pounds. When there are tip, seam, or cap leaks, the tendency will be to cause prompt suction of air and infection of the goods. The swells will occur in a few days and can be removed promptly.

\section{EXAMINATION OF COMMERCIAL CANNED PEAS.}

Peas were purchased from 15 groceries, representing 135 brands, 125 of which were of domestic production and 10 were imported. With the exception of 5 brands, the domestic peas were put up in standard No. 2 cans. The average weight of a can of peas was found to be 705 grams (25.2 ounces); the can, 103 grams (3.66 ounces); the peas, after the liquor was allowed to drain through a sieve for one minute, 394 grams (14 ounces), and the liquor, 208 grams (7.5 
ounces). The variation in the total weight was between 650 and 735 grams; the can between 95 and 110 grams; the peas between 301 and 605 grams; and the liquor between 0 and 300 grams.

In the experimental work it was determined that a well-filled can should have 400 grams of peas and 200 grams of liquor, and the average for the commercial brands is essentially the same. When a

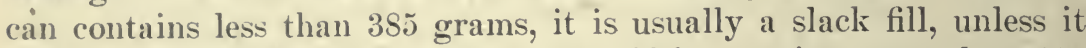
contains marrowfat or telephone peas; if it contains more than 415 grams, the peas will be overcrowded or the liquor will be poor. If these figures are accepted as a fair standard. 30 per cent of the cans were short weight on fill of peas and 20 per cent contained an overweight of peas.

The peas were graded for size by shaking them through sieves containing standard-sized holes; 74 per cent were found to be true to the label; 17.3 per cent were found to be larger than represented; and 8. 7 per cent were smaller than was claimed.

The peas were also tested for quality by suspending a sample in a salt solution having a specific gravity of 1.075 . Peas of known quality before being canned were used as a standard, and it was found that first-class tender peas would float in such a solution, while the pooreı, hard peas would sink. Assuming such a test to be fair for quality, it was found that 53 per cent were true to the label; $41 . \overline{\mathrm{per}}$ cent below the grade claimed; and 5.3 per cent above the grade claimed.

These figures are not at all surprising. The high-grade and higherpriced goods are usually what they purport to be, or better. and the poor goods are offered as being of a high quality. Peas which are manifestly too poor to be sold as coming from a factory without inpairing its reputation are sold under other guises, but with labels claiming high quality. "Telephone" and "marrowfat" peas are generally sold as "early June" peas. From 8 to 16 per cent of the pack consist of these large peas, but they are seldom found on the grocer's shelves. In the high-class peas the "sifted" peas are sold as "early June" and the "extra sifted" as "sifted" peas. The lack of uniform grading and the use of individual names accounts in some measure for the present condition in the trade. The fact that no method of grading peas for quality at the factory has come into general use also explains in a measure the lack of a standard for the canned article. This condition will probably change within the next few years. The nutritive property of the peas, whether of one size or another, or one degree of tenderness or another of hardness, is not brought into question: but trade and custom have established that young tender peas of a certain size should be so designated, and that the inferior. hard, overripe article should not be confused with them.

A comparison of the peas packed in 1908-though a poor yearwith peas of the same brand of previous years shows a marked im- 
provement in the latest pack. A comparison of the domestic pack with the foreign brands of the same grade and price is decidedly in favor of the home-grown in evenness of size, tenderness, and flavor. The foreign pea is of a brighter green color, due to using a coppes salt. The foreign peas are also misbranded in some cases as to size and quality.

\section{SPOILAGE.}

The spoilage in canned peas may be classified under three heads: (1) That due to leaks in the can; (2) to insufficient processing; and (3) to spoilage prior to the canning.

The spoilage due to leaks is largely a matter of carelessness in inspection. The manufacturers of cans allow two cans per thousand for defects in material or imperfect union on the side, top, or bottom seans. This appears to be an ample allowance, as some of the largest factories find less than one "spoil" per thousand due to such causes. Tip leaks and cap leaks are much more common than end or side leaks, these being due to incompetent workers and lax inspection. Cap and tip leaks become most numerous when long runs are made and the workmen becone tired. When night runs are made, the greater number of leaks are found to occur in cans handled in the early morning.

Leaks may be found later in goods kept in a damp warehouse. The tin may be more or less broken where the bend is made on the ends, and an excess of moisture may cause it to rust through along the edges. The rusting may be very slow, but it will gradually affect a considerable percentage of cans. Spoilage due to leaks usually occurs early-much of it within twenty-four hours-and, as a rule, there are several forms of bacteria present, among which there are nearly always some that will cause swelling. A leak may not be apparent without a careful inspection: the hole may be so small as to be plugged by a piece of tissue, or the swelling of the can may producs such a strain as to prevent the escape of gas or contents. By cutting the can and tearing the seams, the points at which the solder failed to eatch may be detected.

Goods spoiled owing to insufficient processing are generally classed as "swells" and "sours." Formerly spoilage of this character was a serious matter, but the discovery of the cause and the means of prevention has decreased the loss from this source. At first No. 2 cans were boiled in open kettles from one to three hours, and the losses were not considered large, although the percentage would probably be considered high at this time. Later the processing was done in a retort at a higher temperature than that of boiling water, in order to reduce the time. The practice at many of the factories was to give a temperature of $230^{\circ} \mathrm{F}$. for from ten to fifteen minutes. Swells and sour peas resulted, and the cause was not understood. In 1895 
Russell ${ }^{a}$ investigated the cause of swells in peas and, finding them to be due to bacterial infection as a result of insufficient processing. he recommended that the process be changed from ten and eleven minutes at $230^{\circ} \mathrm{F}$. to fifteen minutes at $242^{\circ} \mathrm{F}$. The losses from swells at this higher temperature were very small, and consequently this temperature was recommended to the Wisconsin packers.

In 1896 Prescott and Underwood ${ }^{b}$ began the study of swelled and sour corn and later turned their attention to sour peas. In February. 1901, they presented a paper before the American Canners' Association on the cause of sour peas, and from their experiments determined that the cause was underprocessing. As a result of these investigations, they recommended a process at $240^{\circ} \mathrm{F}$. for thirty-five minutes or $236^{\circ} \mathrm{F}$. for forty minutes. The experiments reported at that time became the basis of the process for a very large part of the pea canning.

Harding and Nicholson, ${ }^{c}$ of the New York experiment station, studied the swelling of peas, and gave a detailed description of the organism to which it was ascribed. They found that a process at $240^{\circ} \mathrm{F}$. for thirty minutes was effective in preventing swells, and made such a recommendation for the prevention of losses.' Other writers have advocated a longer process at this temperature or a higher temperature in order to prevent spoilage, and many factories have adopted a heavier process-some to the extent of greatly overcooking their goods.

The writer processed a series of experimental goods for the purpose of studying the various forms of spoilage, but with negative results. All cans processed for fifteen minutes cr more at $240^{\circ} \mathrm{F}$. were sterile. and those processed at a lower temperature and for a shorter time usually had a mixed infection. The resulting spoilage was so much less than that given by other writers and generally found in practice that it would seem unwise to make recommendations based upon one year's work.

The spoilage occurring before the peas enter the can is due to allowing them to stand in piles, on the wagons or after thrashing, until they heat and start fermentation. If the peas are kept moving from the vine to.the can, the spoilage from this source is very small. If hulled and thoroughly washed in cold water at short periods, they may be kept for some time without appreciable spoilage. Peas held on the vines longer than they should be, through accidents or overcrowding, will not deteriorate to such an extent as to become unfit for use if the vines are kept loose and the peas are well washed as soon as hulled. The pods may become wet and even sticky before the

${ }^{a}$ Wisconsin Agr. Exp. Sta. Rep., 1S95, pp. 227-231.

${ }^{\natural}$ Prescott, S. C., and Underwood, L. M., Technology Quarterly, 1S9S, 11 : 1 .

${ }^{c}$ New York Agr. Exper. Sta., Genera, 1903, Bul. 249. 
peas sour. Thorough washing and extra blanching are necessary, and if properly conducted no change in acidity or in other characteristics will be apparent, save a slightly cloudier liquor. Such peas lose some of their natural sweetness, because the sugar undergoes a change while standing; they are not, therefore, first grade, but neither are they spoiled or unfit for use if rightly handled.

The need for prompt handling of the peas after they have been cut is shown in the change in the pea, as well as in the infection which causes spoilage. The experiments made to determine these points were conducted when the weather was fairly cool and favorable to the canning of peas, and do not represent either extreme. A quantity of vines equivalent to one-fourth of a wagon load was piled and allowed to stand for 36 hours, samples being taken at intervals and canned without the addition of salt or sugar. A quantity of shelled peas was also allowed to stand, sampled at intervals, and canned as in the preceding case. Tests were then made to determine the relative sugar content, with the following results:

EDect on sugar crontene of lelling press stand before cauning.

\begin{tabular}{|c|c|c|c|}
\hline Time clajwing before caunlog. & $\begin{array}{l}\text { Per cent } \\
\text { of sugur. }\end{array}$ & Tinue elajwing before cunning. & $\begin{array}{l}\text { Per cent } \\
\text { of sugar. }\end{array}$ \\
\hline 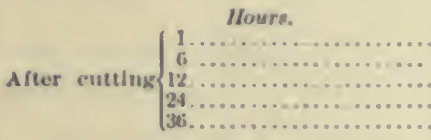 & $\begin{array}{l}2.19 \\
2.25 \\
2.75 \\
2.45 \\
2.23\end{array}$ & 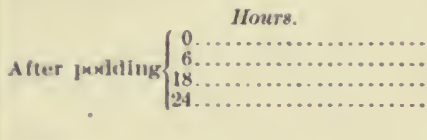 & $\begin{array}{r}2.19 \\
1.65 \\
1.24 \\
.90\end{array}$ \\
\hline
\end{tabular}

The peas taken from the vines at different times showed no constant change in the sugar content. The vines soured slightly, but the appearance of the peas remained unchanged. In increase in the cloudiness of the liquor was observed as the time after cutting was prolonged.

The shelled peas show a gradual and continuous decrease in the sugar content as the time increased. Those standing for eighteen hours were slightly soured, while those standing for twenty-four hours were decidedly sour. These experiments, though planned with special reference to studies in spoilage, show the necessity for prompt handling to insure the highest grade product. One of the eflects of standing is to cause the peas of the first grade to change so as to deteriorate to second or even third grade. This is demonstrated both by the specific gravity test and by the swelling after blanching and processing.

The experiments to determine the influence of delay between the time of cutting the peas and canning them showed so much less effect than is generally assumed in factory practice that the work should be repeated under less favorable conditions before drawing general conclusions. 


\section{BY-PRODUCTS.}

The pea vines are a waste or by-product at many factories. Some pay to have them taken away, some pile them up to rot for fertilizers. some dump them upon the land, others make them into silage, and still others convert them into hay. In general the value of the pea vine for food is only slightly appreciated. The silage can be made either in the silo or by piling in a large stack and rolling well. The latter method is economical, as the expense of a special building is sbriated and, if well done, the losses upon the sides and top are not great. Analyses made by V. J. Jones, jr., Indiana state chemist, on stacked pea-vine and sweet-corn silage gave the following results:

Aualysess of pea-rine and sweet-erorn silage.

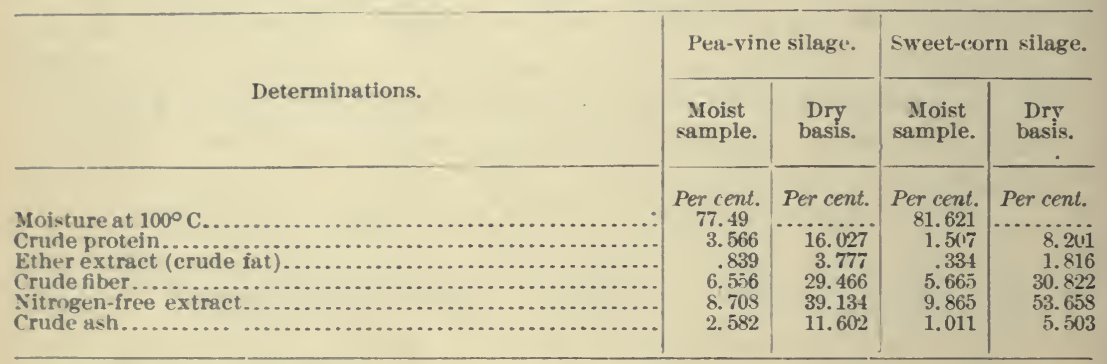

These samples were taken in May from stack silage which had been put up the previous year. A comparison of the analysis of the pea-vine silage with that of the sweet corn shows the former to be much the richer in protein. A comparison with regular corn silage is also favorable to the pea silage. If $\$ 2.50$ a ton is accepted as the value of regular corn silage, the pea-vine product should be worth more. A sample of good pea-vine hay was also analyzed and gave a value between that of clover and timothy. Stock relish both the silage and the hay.

Analysis of pea-rine hay.

\begin{tabular}{|c|c|c|c|c|c|}
\hline Ihetermination. & $\begin{array}{l}\text { Moist sam- } \\
\text { ple. }\end{array}$ & $\begin{array}{c}\text { Caleulated } \\
\text { as dry } \\
\text { matter. }\end{array}$ & Determination. & $\begin{array}{c}\text { Moist sam- } \\
\text { ple. }\end{array}$ & $\begin{array}{l}\text { Calculated } \\
\text { as dry } \\
\text { matter. }\end{array}$ \\
\hline $\begin{array}{l}\text { Moisture............. } \\
\text { Crude protein ....... } \\
\text { Vitrogen-free extract. }\end{array}$ & $\begin{array}{r}\text { Per cent. } \\
7.120 \\
9.760 \\
51.304\end{array}$ & $\begin{array}{c}\text { Per cent. } \\
10.50 \% \\
55.239\end{array}$ & $\begin{array}{l}\text { Fat } \ldots \ldots \ldots \\
\text { Fiber } \ldots \ldots \\
\text { Ash } \ldots \ldots\end{array}$ & $\begin{array}{r}\text { Per cent. } \\
1.720 \\
23.290 \\
6.800\end{array}$ & $\begin{array}{r}\text { Per cent. } \\
1.852 \\
25.074 \\
7.226\end{array}$ \\
\hline
\end{tabular}

These analyses indicate that the by-product has a food value too great to be ignored, and that an effort should be made to transport the vines to the factory in good condition in order to get the best results from them. 

RETURN TO DESK FROM WHICH BORROWED

\section{LOAN DEPT.}

This book is due on the last date stamped below, or on the date to which renewed.

Renewed books are subject to immediate recall.

\section{DAY USE \\ RETURN TO DESK FROM WHICH BORROWED LOAN DEPT. \\ RENEWALS ONLY-TEL. NO. 642-3405}

This book is due on the last date stamped below, or on the date to which renewed.

Renewed books are subject to immediate recall.

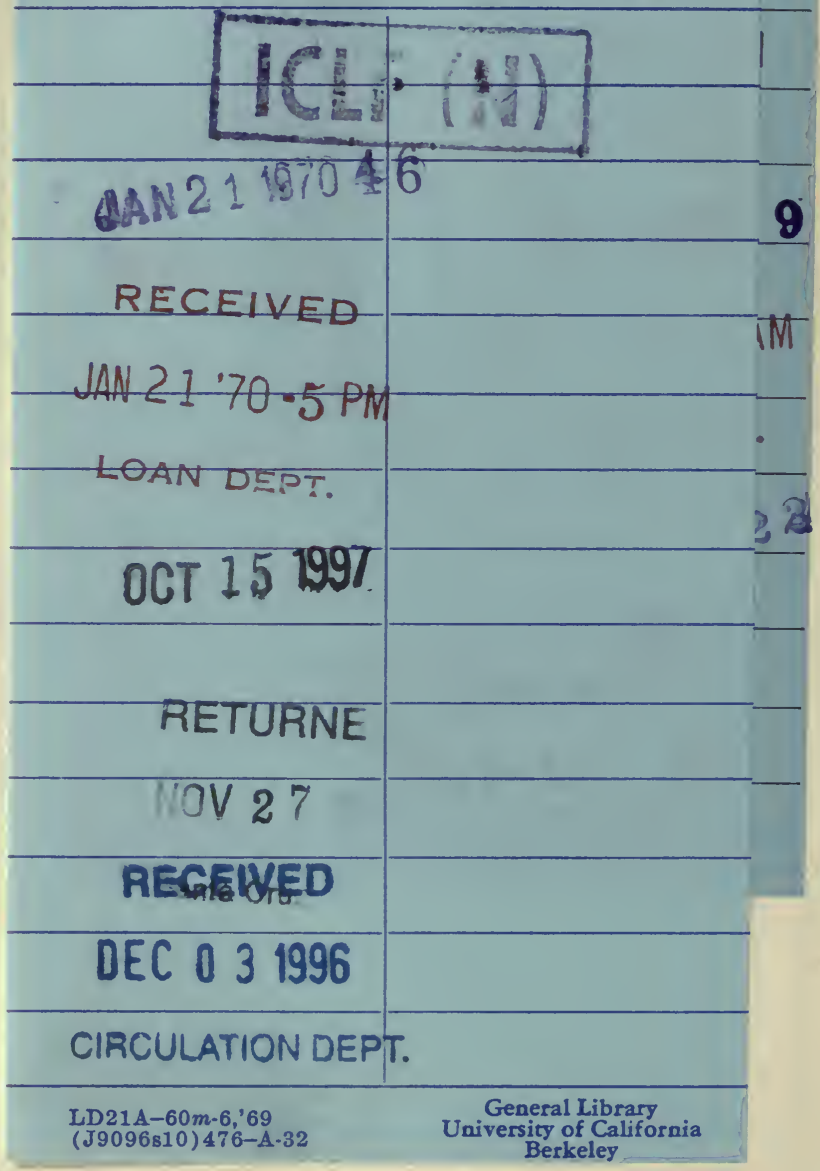


U. C. BERKELEY LIBRARIES

$\therefore \quad \therefore$ -

$\because \div \quad \because \cdots$

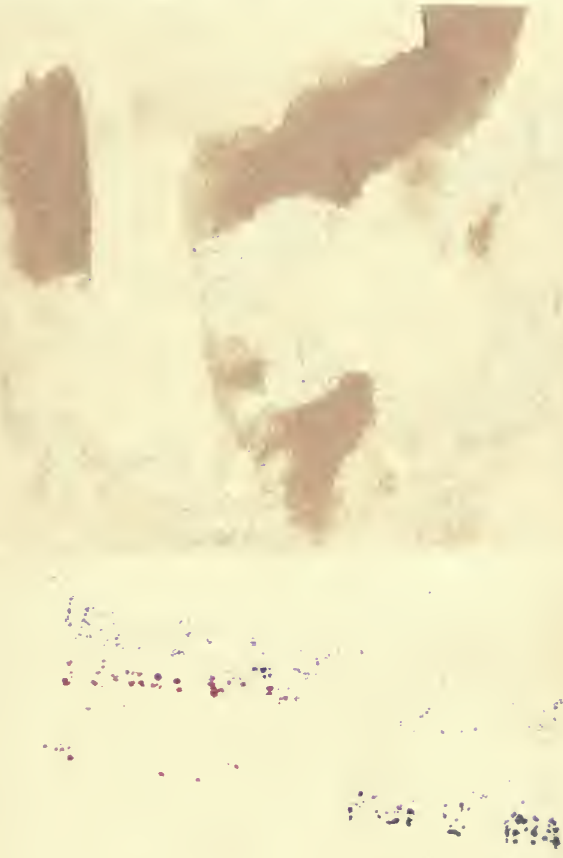


